\title{
Perbandingan Pertumbuhan Bakteri Selulolitik Pada Media Nutrient Broth dan Carboxy Methyl Cellulose
}

\author{
N. Wahyuningsih dan E. Zulaika \\ Departemen Biologi, Fakultas Ilmu Alam, Institut Teknologi Sepuluh Nopember (ITS) \\ e-mail: enny@bio.its.ac.id
}

\begin{abstract}
Abstrak-Kurva pertumbuhan merepresentasikan keseluruhan siklus pertumbuhan bakteri, termasuk fase lag, eksponensial, stasioner dan kematian. Kultivasi mikroba untuk mengetahui pola pertumbuhan bakteri dilakukan dengan berbagai media pertumbuhan yaitu media umum dan media selektif. Tujuan penelitian ini adalah membandingkan pola pertumbuhan isolat bakteri indigenous gambut Kalimantan pada media Nutrient Broth (NB) dan media Carboxy Methyl Cellulose (CMC). Kepadatan sel atau optical density (OD) diukur dengan spektrofotometer UV-Vis $(600 \mathrm{~nm})$. Pola pertumbuhan isolat bakteri pada media NB lebih baik dibandingkan pada media CMC. Fase log pada media NB optimal pada jam ke - 10 dan 12, sedangkan pada media CMC pada jam ke - 8 dan 9. Pada media NB fase kematian belum nampak hingga jam ke - 24, sedangkan pada media CMC fase kematian nampak pada jam ke - 9.
\end{abstract}

Kata Kunci-Carboxy-methyl-cellulose, Bakteri-selulolitik, Kurva-pertumbuhan, Nutrient-broth.

\section{PENDAHULUAN}

P OLA pertumbuhan mikroba umumnya ditunjukkan dengan kurva pertumbuhan. Kurva pertumbuhan merepresentasikan keseluruhan siklus pertumbuhan bakteri, termasuk fase lag, fase eksponensial, fase stasioner dan fase kematian [1]. Fase lag terjadi ketika biakan memasuki habitat atau medium yang baru atau medium yang berbeda dari medium sebelumnya. Pada fase ini bakteri mengalami adaptasi metabolik sel agar dapat bertahan hidup pada lingkungan yang baru. Panjang fase lag ditentukan oleh beberapa faktor seperti spesies bakteri, perubahan kondisi lingkungan dan kondisi biakan pada medium sebelumnya [2]. Apabila biakan sedang mengalami pertumbuhan secara eksponensial kemudian dipindahkan ke dalam medium baru dengan kondisi lingkungan yang sama, maka fase lag tidak terjadi. Ketika biakan dipindahkan dari medium kaya nutrisi ke medium yang memiliki sedikit nutrisi maka biakan akan mengalami fase lag sebab sel perlu komplemen enzim yang lengkap untuk melakukan sintesis metabolit esensial yang ada pada medium yang baru. Oleh karena itu kultur memerlukan waktu untuk beradaptasi pada lingkungan yang baru [1]. Sel yang telah beradaptasi dengan lingkungan atau medium yang baru akan mulai berkembang dan membelah secara eksponensial dan memasuki fase kedua yaitu fase eksponensial atau fase log. Laju pertumbuhan bakteri bergantung pada kondisi lingkungan, apabila kondisi lingkungannya memiliki sedikit nutrisi maka pertumbuhan bakteri secara umum akan lebih lambat daripada pertumbuhan bakteri dengan medium yang kaya nutrisi [3]. Pertumbuhan biakan akan memasuki fase stasioner ketika nutrisi pada medium semakin menipis atau ketika adanya akumulasi produk sampingan lain yang menghambat pertumbuhan bakteri. Pada fase stasioner tidak terdapat penurunan atau kenaikan jumlah sel yang signifikan, sehingga laju pertumbuhan biakan adalah nol. Karena jumlah sel yang membelah dan sel yang mati hampir sama. Tetapi meskipun tidak terdapat pertumbuhan yang siginifikan proses biosintesis dan metabolisme energi sel tetap berlangsung. [1]. Nutrisi pada medium biakan yang terus menipis dan adanya akumulasi produk sampingan yang terjadi terus menerus akan menyebabkan biakan mengalami fase kematian dimana jumlah sel menurun secara bertahap [3]. Fase kematian pada biakan diikuti adanya proses lisis dari masing-masing sel bakteri [1]

Kultivasi mikroba dilakukan dengan berbagai media pertumbuhan. Meida pertumbuhan terdiri dari beberapa macam seperti media pertumbuhan universal atau umum hingga media selektif diferensial. Nutrient Broth (NB) termasuk ke dalam media umum yang digunakan untuk menumbuhkan biakan secara general. NB diformulasikan dengan sumber karbon dan nitrogen supaya dapat memenuhi kebutuhan nutrisi bakteri. Komposisi NB terdiri dari beef extract sebagai sumber karbon dan pepton sebagai sumber nitrogen [4].

Carboxy Methyl Cellulose (CMC) merupakan derivatif dari selulosa yang mengandung gugus carboxymetyl ($\mathrm{CH}_{2} \mathrm{COOH}$ ) yang dihasilkan dari reaksi selulosa dengan chloroacetate dalam alkali untuk memproduksi subtitusi posisi C2, C3 atau C6 pada unit glukosa. Sehingga CMC larut dalam air dan dapat digunakan untuk mengetahui aktivitas hidrolitik selulase [5]. Media CMC termasuk ke dalam media selektif yang digunakan untuk menumbuhkan bakteri yang dapat menghidrolisis selulosa [6].

Penelitian sebelumnya telah melakukan isolasi bakteri dari tanah gambut di Palangkaraya, Kalimantan. Isolat yang didapatkan adalah D1, D2, D3, U2, U3, dan U4. Kurva pertumbuhan pada media NB dari keenam isolat tersebut telah dilakukan [7]. Pada penelitian ini dilakukan perbandingan pola pertumbuhan keenam isolat tersebut dengan menggunakan media NB dan dengan menggunakan media selektif CMC. 


\section{METODOLOGI}

\section{A. Waktu dan Tempat Penelitian}

Penelitian dilakukan pada bulan Februari 2017 hingga Juni 2018 di Laboratorium Mikrobiologi dan Bioteknologi Departemen Biologi Fakultas Ilmu Alam, Institut Teknologi Sepuluh Nopember.

\section{B. Subkultur dalam Media CMC}

Subkultur dilakukan menggunakan medium Carboxy Methyl Cellulose (CMC) agar dengan komposisi $1 \mathrm{~g}$ pepton; $1 \mathrm{~g} \mathrm{CMC} ; 0,2 \mathrm{~g}$ dipotassium phosphat $\left(\mathrm{K}_{2} \mathrm{HPO}_{4}\right)$; $1,5 \mathrm{~g}$ agar; $0,24 \mathrm{~g}$ ammonium sulfate $\left(\mathrm{NH}_{4}\right)_{2} \mathrm{SO}_{4} ; 0,03 \mathrm{~g}$ magnesium sulfat $\left(\mathrm{MgSO} 4.7 \mathrm{H}_{2} \mathrm{O}\right)$ yang dilarutkan dengan akuades hingga $100 \mathrm{~mL}$. Medium disterilkan dengan autoclave pada suhu $121^{\circ} \mathrm{C}$ tekanan 1 atm selama 15 menit dan dibentuk menjadi agar slant. Masing-masing isolat bakteri di ambil sebanyak 1 ose dan diinokulasikan pada media CMC agar, diinkubasi pada suhu ruang selama 72 jam [8]. Keberhasilan subkultur ditandai dengan koloni yang tumbuh pada media.

\section{Kurva Pertumbuhan}

Kurva pertumbuhan dilakukan untuk mengetahui umur dan fase pertumbuhan biakan. Sebanyak 3 ose isolat diinokulasikan ke media CMC cair $100 \mathrm{~mL}$, diinkubasi dalam rotary shaker dengan kecepatan $100 \mathrm{rpm}$ pada suhu ruang $\left(30^{\circ} \mathrm{C}\right)$ selama 24 jam. Kepadatan sel atau optical density (OD) diukur dengan spektrofotometer UV-Vis pada panjang gelombang $600 \mathrm{~nm}$. Pengukuran OD dilakukan dari jam ke 0 - 15 dengan interval waktu 60 menit.

\section{Pembuatan Starter}

Starter dibuat dengan menginokulasikan 3 ose isolat pada $3 \mathrm{ml}$ medium CMC cair. Kultur diinkubasi pada rotary shaker dengan kecepatan $100 \mathrm{rpm}$ pada suhu $30^{\circ} \mathrm{C}$ selama 24 jam. Pada akhir inkubasi kultur tersebut dimasukkan ke dalam $27 \mathrm{ml} \mathrm{CMC}$ cair steril dan diinkubasi pada rotary shaker dengan kecepatan $100 \mathrm{rpm}$ pada suhu $30^{\circ} \mathrm{C}$ selama $\mu$ jam. Pengukuran kepadatan sel dilakukan pada kultur yang berumur $\mu$ jam. Pada penelitian ini umur starter $\mu$ (jam) ditentukan setelah jumlah sel mencapai $10^{8} \mathrm{sel} / \mathrm{ml}$.

\section{HASIL DAN DISKUSI}

\section{A. Subkultur dalam Media CMC}

Subkultur merupakan prosedur pemindahan mikroorganisme dari suatu media ke media yang lain [9]. Subkultur berfungsi untuk memelihara biakan mikroba dengan memindahkan kultur secara berkala di media yang baru. Interval pemindahan kultur bervariasi sesuai jenis mikroorganisme, media dan kondisi penyimpanan. Subkultur dapat dilakukan di media agar miring, atau media cair [10].

Pemindahan isolat pada penelitian ini dilakukan dari medium CMC agar ke dalam medium CMC agar yang baru. Pemindahan isolat dilakukan secara aseptis. Setelah muncul koloni pada media subkultur, biakan disimpan pada suhu $3^{\circ} \mathrm{C}$ hingga $5^{\circ} \mathrm{C}$ untuk mengurangi aktivitas metabolik biakan sehingga dapat memperpanjang kelangsungan hidup biakan tersebut [9]. Koloni tumbuh pada media CMC agar pada jam ke 24 (Gambar 1). Hal itu menunjukkan bahwa keenam isolat dapat menggunakan selulosa sebagai sumber karbon.

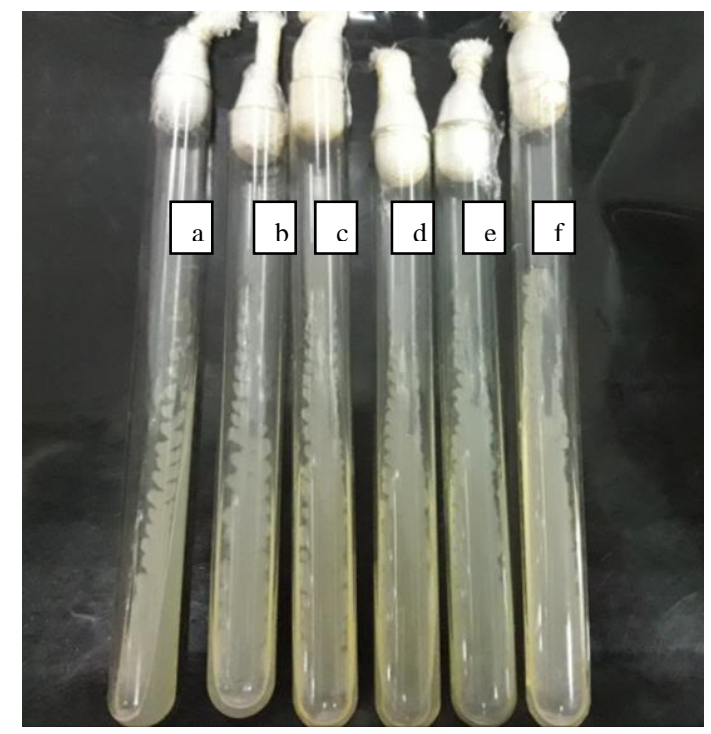

Gambar 1. Subkultur dalam Media CMC.

Keterangan gambar : a) Isolat D1 b) Isolat D2 c) Isolat D3 d) Isolat U2 e) Isolat U3 f) Isolat U4.

\section{B. Pola Pertumbuhan Isolat}

Kurva pertumbuhan diperlukan untuk mengetahui fase pertumbuhan biakan. Fase pertumbuhan dimulai dari fase lag (fase adaptasi), fase eksponensial (fase log), fase stasioner (fase stagnan) dan fase kematian [1]. Kurva pertumbuhan dari semua isolat menunjukkan pola yang hampir sama (Gambar 2 dan Gambar 3). Kurva pertumbuhan dengan media CMC menunjukkan fase lag semua isolat terjadi pada jam ke 0 hingga jam ke 4 , kecuali isolat D1 pada jam ke 0 hingga jam ke 6. Fase eksponensial isolat D1 terjadi pada jam ke 6 hingga jam ke 9, isolat D2 dan D3 pada jam ke 4 hingga jam ke 9 , isolat $\mathrm{U} 2$ dan $\mathrm{U} 3$ pada jam ke 4 hingga jam ke 8 , isolat U4 pada jam ke 4 hingga jam ke 10. Fase stasioner tidak tampak pada kurva pertumbuhan sedangkan fase kematian secara perlahan rata-rata terjadi setelah jam ke 9. Pada penelitian sebelumnya kurva pertumbuhan dengan media Nutrient Broth menunjukkan fase lag semua isolat terjadi pada jam ke 0 hingga jam ke 4 kecuali pada isolat U3 tidak tampak fase lag. Fase eksponensial isolat D1 dan U2 terjadi pada jam ke 4 hingga jam ke 10, isolat D2, D3 dan U4 terjadi pada jam ke 4 hingga jam ke 12, isolat U3 terjadi pada jam ke 0 hingga jam ke 10 . Fase stasioner pada isolat D1 dan U2 terjadi pada jam ke 10 hingga jam ke 24, isolat D2, D3 dan U4 terjadi pada jam ke 12 hingga jam ke 24, isolat U3 terjadi pada jam ke 10 hingga jam ke 24 [7]. Fase log isolat uji pada media NB optimal pada jam ke 10 dan 12, sedangkan pada media CMC optimal pada jam ke 8 dan 9. Pada media NB fase kematian belum nampak hingga jam ke 24, sedangkan pada media CMC fase kematian nampak pada jam ke 9.

Fase stasioner yang tidak tampak pada kurva pertumbuhan di medium CMC dapat disebabkan karena kemampuan keenam isolat dalam memanfaatkan sumber karbon berbentuk selulosa cukup rendah. Selulosa termasuk dalam polisakarida kompleks [11]. Bakteri lebih mudah memanfaatkan sumber karbon sederhana daripada sumber karbon kompleks. Sedangkan pada kurva pertumbuhan di 
medium NB, fase stasioner tampak hingga jam ke 24 karena sumber karbon pada medium NB lebih sederhana dari selulosa. Secara keseluruhan, pola pertumbuhan isolat uji dengan media NB lebih baik daripada dengan media CMC.

Penellitian sebelumnya tentang bakteri selulolitik KE B6 menunjukkan fase eksponensial pada jam ke 0 hingga ke 8 dan fase stasioner pada jam ke 8 hingga ke 16 [12]. Penelitian tentang Bacillus subtilis BY-2 mempunyai fase eksponensial pada jam ke 8 hingga 20 dan fase stasioner pada jam ke 20 hingga 39 [6]. Perbedaan lama waktu pada setiap fase pertumbuhan, dapat disebabkan oleh beberapa faktor diantaranya perbedaan spesies bakteri yang digunakan dan kondisi lingkungan yang berbeda [12].

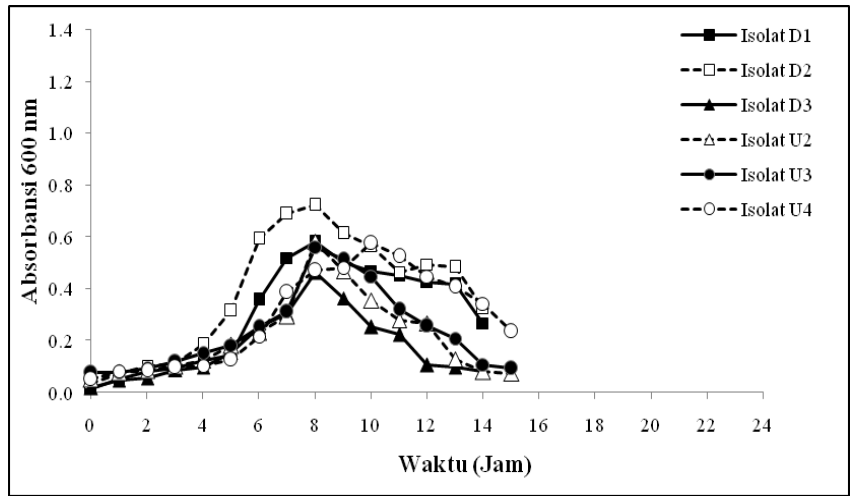

Gambar. 2. Kurva Pertumbuhan Isolat Bakteri Selulolitik pada Medium CMC.

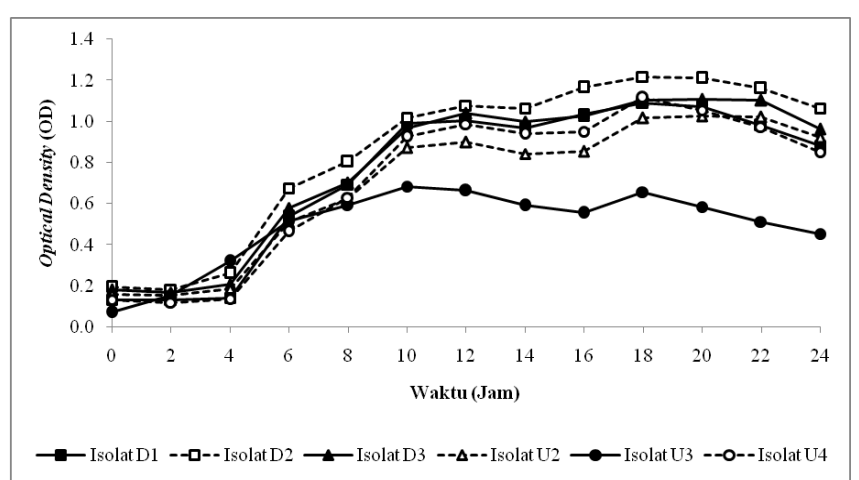

Gambar 3. Kurva Pertumbuhan Isolat Bakteri Selulolitik pada Medium NB [7].

\section{Starter}

Kurva pertumbuhan dapat digunakan untuk menentukan umur starter atau menentukan waktu terbaik untuk perlakuan uji metabolisme. Fase terbaik yang digunakan adalah pada fase eksponensial, sebab pada fase tersebut bakteri memiliki laju pertumbuhan yang optimal sehingga dapat digunakan sebagai inokulum pada suatu perlakuan [12]. Pada penelitian ini umur starter $\mu$ (jam) ditentukan setelah jumlah sel mencapai $10^{8} \mathrm{sel} / \mathrm{ml}$. Semua isolat mempunyai jumlah sel $\mathrm{x}$ $10^{8}$ setelah jam ke 9 , kecuali isolat D1 dan U4 pada jam ke 10 (Tabel 1).

Tabel 1.

Jumlah Sel.

\begin{tabular}{ccc}
\hline \hline Isolat & Jumlah sel $(\mathrm{sel} / \mathrm{ml})$ & Jam ke- \\
\hline D1 & $1,111 \times 10^{8}$ & 10 \\
D2 & $1,255 \times 10^{8}$ & 9 \\
D3 & $1,593 \times 10^{8}$ & 9 \\
U2 & $1,086 \times 10^{8}$ & 9 \\
U3 & $1,079 \times 10^{8}$ & 9 \\
U4 & $1,540 \times 10^{8}$ & 10 \\
\hline \hline
\end{tabular}

\section{KESIMPULAN/RINGKASAN}

Fase log isolat uji pada media NB optimal pada jam ke 10 dan 12, sedangkan pada media CMC optimal pada jam ke 8 dan 9. Pada media NB fase kematian belum nampak hingga jam ke 24, sedangkan pada media CMC fase kematian nampak pada jam ke 9. Sehingga pola pertumbuhan keenam isolat dengan media NB lebih baik daripada dengan media CMC.

\section{DAFTAR PUSTAKA}

[1] D. P. Madigan, M. T., Martinko, J. M., Stahl, D., dan Clark, Brock Biology of Microorganisms (13th Edition). New York: Pearson, 2012.

[2] C. P. and J. Baranyi, "Single-cell and Population Lag Times As A Function of Cell Age," Appl Env. Microb, vol. 74, pp. 25342536, 2008.

[3] A. T. and E. M. G. J.M.N. Llorens, "Stationary Phase In Gram negative Bacteria," FEMS Microbiol., pp. 476-495, 2010.

[4] M. J. L. and B. E. Pierce, Microbiology Laboratory Theory \& Application Third Edition. Colorado: Morton Publishing, 2005.

[5] H. J. Gilbert, Cellulases Volume 510 of Methods In Enzymology. Cambridge: Academic Press, 2012.

[6] and C. B. W. Yang, M. Fanxu, P. Jiayin, H. Peng, F. Fang, M. $\mathrm{Li}$, "Isolation and Identification of A Cellulolytic Bacterium from The Tibetan Pig's Intestine and Investigation of Its Cellulase Production," Electron. J. Biotechnol., vol. 17, pp. 262-267, 2014.

[7] and E. Z. F. Solikhah, "Bakteri Lignoselulolitik Lahan Gambut Sebagai Alternatif Untuk Mempercepat Dekomposisi Serat Gambut," Institut Teknologi Sepuluh Nopember, 2018.

[8] and H. H. L. L.J. Yin, P.S. Huang, "Isolation Of CellulaseProducing Bacteria And Characterization Of The Cellulase From The Isolated Bacterium Cellulomonas sp. YJ5," J Agric Food Chem, vol. 58, no. 17, pp. 9833-9837, 2010.

[9] K. R. Aneja, Experiments in Microbiology, Plant Pathology and Biotechnology. New Delhi: New Age Intermnational, 2007.

[10] et al M.P. Starr, The Prokaryotes: A Handbook on Habitats, Isolation and Identification of Bacteria. Berlin: Springer Science \& Business Media, 2013.

[11] J. M. Berg, Biochemistry, Sixth. New York: W.H. Freeman, 2007.

[12] and P. S. Wijanarka., K. Endang, "Screening Cellulolytic Bacteria from The Digestive Tract Snail (Achatina fulica) and Test the Ability of Cellulase Activity," Biosaintifika, vol. 8, no. 3, pp. 386-392, 2016. 